ISSN 1392-3196 / e-ISSN 2335-8947

Zemdirbyste-Agriculture, vol. 103, No. 1 (2016), p. 77-82

DOI $10.13080 /$ z-a.2016.103.010

\title{
Plant growth promoting and antagonistic properties of endophytic bacteria isolated from domestic apple
}

\author{
Inga MILIUTE ${ }^{1}$, Odeta BUZAITE ${ }^{1,2}$, Dalia GELVONAUSKIENE ${ }^{1}$, Audrius SASNAUSKAS ${ }^{1}$, \\ Vidmantas STANYS ${ }^{1,3}$, Danas BANIULIS ${ }^{1}$ \\ ${ }^{1}$ Institute of Horticulture, Lithuanian Research Centre for Agriculture and Forestry \\ Kauno 30, Babtai, Kaunas distr., Lithuania \\ E-mail: d.baniulis@1sdi.lt \\ ${ }^{2}$ Vytautas Magnus University \\ Vileikos 8, Kaunas, Lithuania \\ ${ }^{3}$ Aleksandras Stulginskis University \\ Studentų 11, Akademija, Kaunas distr., Lithuania
}

\begin{abstract}
Bacterial endophytes are common inhabitants of plant tissues that have been shown to play an important role in regulation of plant growth and to have the potential as biological agent for plant disease protection. Only fragmented knowledge is present about endophytes that reside in the phyllosphere of cultivated tree plants such as domestic apple (Malus $\times$ domestica Borkh.). Therefore the goal of this study was to identify culturable endophytic bacteria characteristic of an apple phyllosphere and to establish biochemical traits involved in plant growth promoting activity as well as to study microbial growth suppressing activity of the endophytes. Thirty-eight putative endophytic bacteria were isolated from apple buds of cultivars 'Gala', 'Golden Delicious' and 'Orlovim' grown under field conditions and 13 of the isolates were assigned to Curtobacterium, Pantoea and Pseudomonas species. Biochemical tests revealed traits important for plant growth stimulation and microbial growth suppression characteristics of the isolates, including nitrogen fixation, production of indole-3-acetic acid (IAA), phosphate solubilization, production of siderophores and hydrogen cyanide. Several isolates displayed antagonistic activity against selected non-pathogenic and pathogenic bacterial strains: 17 isolates were able to inhibit growth of Micrococcus luteus, 4 - Pseudomonas aeruginosa, 2 - Escherichia coli and Bacillus subtilis. In addition, it was determined that two isolates of Pantoea sp. (D_8 and D_10) and Pseudomonas fluorescens group isolate D_7 were able to inhibit growth of the apple scab pathogen (Venturia inaequalis (Cke) Wint.), suggesting a role of the endophytes in disease resistance and a potential use for biocontrol applications.
\end{abstract}

Key words: antimicrobial activity, biocontrol, Malus $\times$ domestica, phyllosphere.

\section{Introduction}

Endophytic bacteria are microorganisms that live in internal plant tissues where they do not normally cause any substantial disease symptoms. The nonpathogenic interaction with endophytes modulates plant physiological responses such as growth, stress tolerance and disease response (Rodriguez et al., 2008). Many of the previous studies have been focused on plant-microbial interactions in the rhizosphere of wild and cultivated plant species (Rosenblueth, Martinez-Romero, 2006). A phyllosphere has less microbial diversity; however, it is a ground where endophytes may have an important direct plant growth promoting activity and play a role in plant defense against pathogenic microorganisms. It was reported that environmental conditions and agricultural practices may have influence on the composition of endophyte population and reduction of its biological diversity (Rodriguez et al., 2008); therefore it is important to elucidate the composition of endophytic microbiome of economically important plants and its role in productivity and disease resistance of the host plant.

Domestic apple (Malus $\times$ domestica Borkh.) is one of the main economically important fruit crops of temperate regions. Previously, several studies have been published that described endophytic microorganisms of Malus sp. plants, including fungi and bacteria. Isolation of fungal endophytes from leaves, flowers and fruits of healthy $M . \times$ domestica apple trees growing in southern Brasilia revealed presence of genera of Colletotrichum, Xylaria and Botryosphaeria for filamentous fungi and Sporobolomyces, Rhodotorula, Debaryomyces and Cryptococcus for yeast (Camatti-Sartori et al., 2005). Fungus Epicoccum nigrum has been studied as the endophyte commonly present in apple and other crops (Camatti-Sartori et al., 2005). Bulgari and co-authors (2012) characterized bacterial populations of healthy and phytoplasma infected apple roots using culture- 
dependent and independent methods. The cultureindependent analysis showed presence of Proteobacteria, Acidobacteria, Bacteroidetes, Actinobacteria, Chlamydiae and Firmicutes bacterial classes including 24 and 17 taxonomic units in healthy and infected roots. Culture-dependent analysis identified firmicutes of the genus Bacillus, Lysinibacillus Paenibacillus and gammaproteobacteria of the genus Pseudomonas. Cai and Wang (2012) isolated 217 endophytic fungi of 22 different taxa from Malus sieboldii in China. Our previous pilot study revealed the presence of culturable bacteria in apple buds that demonstrated plant growth promoting properties (Miliūtè, Buzaite, 2011).

The goal of this research was to identify culturable endophytic bacteria characteristic of an apple phyllosphere and to establish biochemical traits involved in plant growth promoting activity as well as the microbial growth suppression activity that might have the potential for pathogen biocontrol.

\section{Materials and methods}

Bacterial and fungal strains. Bacterial strains of Micrococcus luteus (DSM 20030), Bacillus subtilis (YB886), Escherichia coli (K12), Pseudomonas aeruginosa (PAO1) and Salmonella typhimurium (SL 1344) were commercially obtained and maintained on lysogeny broth (LB) agar medium (Sigma-Aldrich, Germany). Venturia inaequalis strain No. L-4 was isolated from apple leaves at the collection of apple genetic resources at the Institute of Horticulture, Lithuanian Research Centre for Agriculture and Forestry and was maintained on $4 \%$ malt extract medium.

Isolation and identification of bacteria. The study was conducted in 2012. Apple buds were collected from mature trees of cultivars 'Gala', 'Golden Delicious' and 'Orlovim' grown in the field collection at the Institute of Horticulture, Lithuanian Research Centre for Agriculture and Forestry. The buds were sterilized as described by Hata et al. (2002). The buds were mechanically homogenized and placed on lysogeny broth nutrient media and actinomycete agar (SigmaAldrich, Germany) and incubated for 24 to 48 hours depending on bacterial colony growth. For control of the sterilization efficiency, intact buds were incubated on the nutrient medium after the sterilization. Absence of bacterial growth on control plates with sterilized intact buds indicated that the bacterial isolates originated from the inner tissues of the buds. Deoxyribonucleic acid (DNA) from bacterial cells was extracted using GeneJET Genomic DNA Purification Kit (Thermo Fisher Scientific, Lithuania) and sequence of the D1 region was amplified using universal bacterial primers (Weisburg et al., 1991). PCR product was separated by electrophoresis on a $1.5 \%$ agarose gel, extracted using Mini DNA Purification Kit (Thermo Fisher Scientific, Lithuania) and sequenced. The obtained sequences were compared with the sequences of $16 \mathrm{~S}$ rRNA gene at the NCBI Gene database (Brown et al., 2015).

Metabolic tests. Semisolid nitrogen-free medium, used for screening bacteria capable of fixing nitrogen, was prepared as described (Elbeltagy et al., 2001). Siderophore production was detected by growth on the chrome azurol S medium prepared as described by Vellore (2001). Ability to solubilize tricalcium phosphate was tested according to Mehta and Nautiyal (2001). Methylotrophy was detected by ability to use methanol as a single carbon source on the methanol minimal salts medium. Production of hydrogen cyanide $(\mathrm{HCN})$ was assessed using the method described by Ahmad et al. (2008). Synthesis of indole-3-acetic acid (IAA) was estimated colorimetrically using the ferric chlorideperchloric acid reagent (Gordon, Weber, 1951). The amount of IAA was estimated using a standard curve and normalized based on protein content estimated by the copper-neocuproine method (Sozren et al., 2006). Mean and standard deviation was estimated using software MS Excel.

Analysis of antagonistic properties. Fifty microliters of the test bacteria culture were suspended in $10 \mathrm{ml}$ of melted agar and inoculated on top of LB medium. Sterile cellulose discs were placed on agar surface and soaked with $30 \mu \mathrm{l}$ of each tested bacterial isolate suspension. Plates were incubated for $48 \mathrm{~h}$, and then inhibition zones around the discs were estimated. Micrococcus luteus, Bacillus subtilis, Escherichia coli, Pseudomonas aeruginosa PAO and Salmonella typhimurium SL 1344 were used as the test strains. For fungal inhibition assay, $50 \mu \mathrm{l}$ of conidia suspension $(2.5$ $\times 10^{5}$ conidia $\mathrm{ml}^{-1}$ ) of the apple pathogen $\mathrm{V}$. inaequalis isolate No. L-4 was inoculated in $10 \mathrm{ml}$ of top agar. Suspensions of bacterial isolates were centrifuged and filter sterilized using $0.2 \mu \mathrm{m}$ filter, then $30 \mu \mathrm{l}$ of the filtrate transferred on cellulose disks on agar surface. The plates were incubated for $48 \mathrm{~h}$, and then inhibition zones around discs were estimated. To confirm the antagonistic properties of test strains sterile cellulose discs placed on agar surface were soaked with the same volume of sterile water for negative control or $50 \mu \mathrm{g} \mathrm{ml}^{-1}$ solution of commercial fungicide partricin (Biochrom, Germany) for positive control.

\section{Results and discussion}

Thirty-eight culturable bacterial strains were isolated from sterilized buds collected from the apple cultivars 'Gala', 'Golden Delicious' and 'Orlovim' grown under field conditions. Based on the D1 region sequences of 16S rRNA gene, thirteen of the putative endophytic bacteria could be assigned to four systematic clusters (Table 1). Isolates $\mathrm{O} 11$ and $\mathrm{Da} 2$ (derived from cvs. 'Orlovim' and 'Golden Delicious', respectively) showed high identity level to Curtobacterium sp. Isolates $\mathrm{Ga} 5$ (cv. 'Gala'), D 8 and D 10 (cv. 'Golden Delicious') were identified as Pantoēa sp., O_16 (cv. 'Orlovim') was identified as Pseudomonas stutzeri, and seven of the isolates Oa_2, Oa_14, O_10 (cv. 'Orlovim'), D_7, (cv. 'Golden Delicious') and $\overline{\mathrm{Ga}}$ _1, Ga_3, Ga_4 (cv. 'Gala') showed high similarity to the $\bar{P}$. fluorescens group. Sequences used for comparison were not identical for the two isolates of Curtobacterium and the three isolates of Pantoea. The seven isolates of Pseudomonas fluorescens group showed high sequence identity.

While partial sequences of the D1 region of $16 \mathrm{~S}$ rRNA gene used for comparison were identical for four of the isolates $\mathrm{Oa} 2, \mathrm{O} 14, \mathrm{D} 7$ and $\mathrm{Ga} 3$, the bacteria demonstrated distinct biochemical traits (Table 2 ).

Plant growth promoting properties of the bacterial strains isolated from the apple buds were assessed using metabolic tests. The most important role in plant growth stimulation by the bacterial endophytes plays production of phytohormones such as IAA, gibberellins and cytokinins. IAA is the phytohormone that stimulates cell division and formation of plant roots (Davies, 2010), and it has been shown to have a stabilizing effect under unfavourable environmental conditions (Bianco et al., 2009). In our study, application of the ferric 
Table 1. Identified endophytic bacterial isolates obtained from apple tree buds

\begin{tabular}{|c|c|c|c|c|}
\hline $\begin{array}{c}\text { Strain } \\
\text { code }\end{array}$ & $\begin{array}{c}\text { Number } \\
\text { of aligned } \\
\text { bases }\end{array}$ & $\begin{array}{l}\text { Taxa corresponding to highest identity match of } \\
\text { sequences (accession number) }\end{array}$ & $\begin{array}{c}\text { Identity } \\
\text { match } \\
\%\end{array}$ & Reference \\
\hline Oa 2 & 1442 & Pseudomonas fluorescens group $(028986.1,025586.1)$ & 99.7 & Behrendt et al., 2003 \\
\hline O_- 10 & 1421 & Pseudomonas fluorescens group (028986.1, 025586.1) & 99.6 & Behrendt et al., 2003 \\
\hline $\mathrm{O}_{-}^{-} 11$ & 1269 & Curtobacterium flaccumfaciens LMG 3645 (025467.1) & 99.1 & Behrendt et al., 2002 \\
\hline O_-14 & 1441 & Pseudomonas fluorescens group $(028986.1,025586.1)$ & 99.6 & Behrendt et al., 2003 \\
\hline $\mathrm{O}_{-}^{-} 16$ & 1433 & Pseudomonas stutzeri A1501 (074829.1) & 100 & Yan et al., 2008 \\
\hline $\mathrm{Da} \_2$ & 1101 & Curtobacterium flaccumfaciens LMG 3645 (025467.1) & 99.2 & Behrendt et al., 2002 \\
\hline $\mathrm{D} \overline{7}$ & 1419 & Pseudomonas fluorescens group (028986.1, 025586.1) & 99.7 & Behrendt et al., 2003 \\
\hline $\mathrm{D}-8$ & 1439 & Pantoea sp. $(102966.1,041978.1)$ & 98.2 & Smits et al., 2010 \\
\hline D_ 10 & 985 & Pantoea vagans C9-1 (102966.1) & 98.7 & Smits et al., 2010 \\
\hline Ga_1 & 1418 & Pseudomonas fluorescens group $(102514.1,028987.1)$ & 99.8 & Behrendt et al., 2003 \\
\hline $\mathrm{Ga}^{-} 3$ & 1394 & Pseudomonas fluorescens group (028986.1, 025586.1) & 99.6 & Behrendt et al., 2003 \\
\hline $\mathrm{Ga} 4$ & 998 & Pseudomonas fluorescens group (025103.1) & 99.8 & Baida et al., 2002 \\
\hline $\mathrm{Ga}^{-} 5$ & 1431 & Pantoea vagans C9-1 (102966.1) & 99.6 & Smits et al., 2010 \\
\hline
\end{tabular}

Table 2. Properties of endophytic bacteria isolates from apple

\begin{tabular}{|c|c|c|c|c|c|c|c|c|c|c|c|c|}
\hline \multirow[b]{2}{*}{ Isolates } & \multirow[b]{2}{*}{ 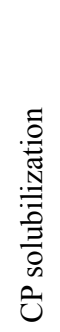 } & \multirow[b]{2}{*}{ 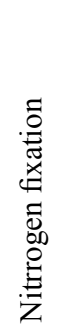 } & \multirow[b]{2}{*}{ 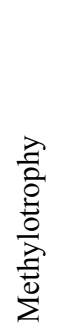 } & \multirow[b]{2}{*}{ 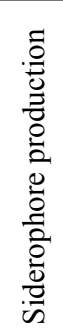 } & \multirow[b]{2}{*}{ 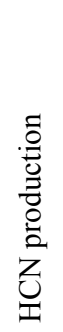 } & \multirow[b]{2}{*}{ 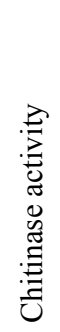 } & \multicolumn{5}{|c|}{ Bacterial growth inhibition } & \multirow[b]{2}{*}{ 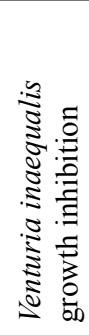 } \\
\hline & & & & & & & 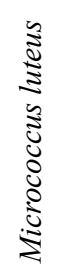 & 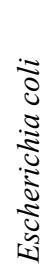 & 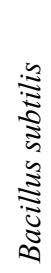 & 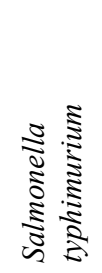 & 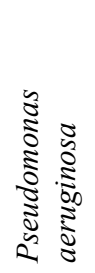 & \\
\hline Oa 1 & - & + & + & + & - & - & + & - & - & - & - & - \\
\hline $\mathrm{Oa}^{-2}$ (Pseudomonas fluorescens group) & + & + & - & - & - & + & + & - & - & - & - & - \\
\hline $\mathrm{Oa} 33$ & - & - & - & + & - & - & - & - & - & - & - & - \\
\hline $\mathrm{Oa}_{-}^{-} 4$ & + & + & + & + & - & - & + & - & - & - & - & - \\
\hline $\mathrm{Oa}^{-5}$ & + & - & + & + & - & - & - & - & - & - & - & - \\
\hline $\mathrm{Oa}^{-} 6$ & - & - & - & + & - & - & + & + & + & - & - & - \\
\hline $\mathrm{Oa}_{-7}^{-}$ & - & - & - & - & - & - & - & - & - & - & - & - \\
\hline $\mathrm{Oa}^{-} 8$ & + & + & - & + & - & - & - & - & + & - & - & - \\
\hline Oa_9 & - & - & - & - & - & - & - & - & - & - & - & - \\
\hline O 10 (Pseudomonas fluorescens group) & + & + & - & + & + & + & + & - & - & - & - & - \\
\hline O_11 (Curtobacterium flaccumfaciens) & + & - & - & + & - & + & - & - & - & - & - & - \\
\hline $\mathrm{O}^{-} 12$ & - & - & + & + & - & + & - & - & - & - & - & - \\
\hline $\mathrm{O}^{-} 13$ & - & - & - & + & - & + & + & - & - & - & - & - \\
\hline $\mathrm{O}^{-14}$ (Pseudomonas fluorescens group) & - & + & + & + & + & + & - & - & + & - & - & - \\
\hline O_15 & + & + & + & + & - & - & + & - & - & - & + & - \\
\hline $\mathrm{O}^{-} 16$ (Pseudomonas stutzeri) & - & + & + & + & - & + & + & - & - & - & - & - \\
\hline Da__1 & + & + & + & + & - & - & - & - & - & - & - & - \\
\hline Da_2 (Curtobacterium flaccumfaciens) & - & + & + & + & - & - & - & - & - & - & - & - \\
\hline $\mathrm{Da}_{-} 3$ & - & - & - & - & - & - & - & - & - & - & - & - \\
\hline $\mathrm{Da}_{-}^{-} 4$ & - & - & - & - & - & - & - & - & - & - & - & - \\
\hline Da_5 & - & + & + & + & - & - & - & - & - & - & - & - \\
\hline$D_{-} \overline{6}$ & - & + & - & + & - & - & - & - & - & - & - & - \\
\hline D_7 (Pseudomonas fluorescens group) & - & + & - & - & - & - & - & - & - & - & - & + \\
\hline D_8 (Pantoea sp.) & + & + & + & + & + & + & - & - & - & - & - & + \\
\hline D_9 & + & + & - & + & - & - & + & + & - & - & - & - \\
\hline D_10 (Pantoea $\mathrm{sp})$. & - & + & - & + & - & - & + & - & - & - & - & + \\
\hline Ga_1 (Pseudomonas fluorescens group) & - & + & - & - & + & - & + & - & - & - & + & - \\
\hline $\mathrm{Ga}^{-} 2$ & - & + & + & + & + & + & + & - & - & - & + & - \\
\hline Ga_3 (Pseudomonas fluorescens group) & - & + & + & + & - & - & + & - & - & - & - & - \\
\hline $\mathrm{Ga}^{-} 4$ (Pseudomonas fluorescens group) & + & + & + & + & - & - & - & - & - & - & - & - \\
\hline Ga_5 (Pantoe sp.) & - & + & + & + & + & + & - & - & - & - & - & - \\
\hline $\mathrm{Ga}_{-}^{-} 6$ & - & - & + & + & - & - & + & - & - & - & - & - \\
\hline $\mathrm{Ga}_{-}^{-} 7$ & - & - & - & - & - & + & - & - & - & - & - & - \\
\hline $\mathrm{G}$ & - & + & - & - & - & + & + & - & - & - & - & - \\
\hline $\mathrm{G}_{-}^{-} 9$ & - & - & - & - & - & - & + & - & - & - & - & - \\
\hline $\mathrm{G}^{-} 10$ & + & + & - & + & + & - & - & - & - & - & + & - \\
\hline $\mathrm{G}_{-}^{-11}$ & - & + & + & + & - & + & + & - & - & - & - & - \\
\hline $\mathrm{G}_{-}^{-} 12$ & - & + & - & - & + & - & - & - & - & - & - & - \\
\hline Total positive & 12 & 25 & 17 & 27 & 8 & 13 & 17 & 2 & 3 & 0 & 4 & 3 \\
\hline
\end{tabular}

Note. Plus and minus indicate positive and negative results of the tests, respectively. $\mathrm{CP}$ - calcium phosphate, $\mathrm{HCN}-$ hydrogen cyanide. 
chloride-perchloric acid (Gordon, Weber, 1951) method to assess IAA production in broth culture demonstrated that half of the putative endophytic isolates from apple produced significant levels of IAA (Fig. 1). Mean value of concentrations of IAA varied approximately five-fold from approx. 10 to $68 \mu \mathrm{g} \mathrm{ml}^{-1}$ of bacterial protein content. Among the identified isolates, Pantoea sp. (Ga 5 and D_8) were the largest producers of IAA. Pseudomonas fluorescens group (Ga_1, Oa_2, D_6), P. vagans (D_10) and P. stutzeri (O_16) produced moderate to low quantities of IAA. Other authors reported varying levels of IAA production for different endophytic strains: $18.8 \mu \mathrm{g} \mathrm{ml}{ }^{-1}$ for $P$. stutzeri, isolated from Echinacea (Lata et al., 2006), 6-13.3 $\mu \mathrm{g} \mathrm{ml}^{-1}$ for Methylobacterium, isolated from clover, $0.6-45.5 \mu \mathrm{g} \mathrm{ml}^{-1}$ for endophytes from Sedum alfredii and 1.1-154 $\mu \mathrm{g} \mathrm{ml}^{-1}$ for endophytes from Solanum nigrum (Raddadi et al., 2008).

Often, nitrogen is the limiting nutrient for plant growth therefore the ability of endophytes to fix atmospheric nitrogen would benefit plant growth and the nitrogen fixing

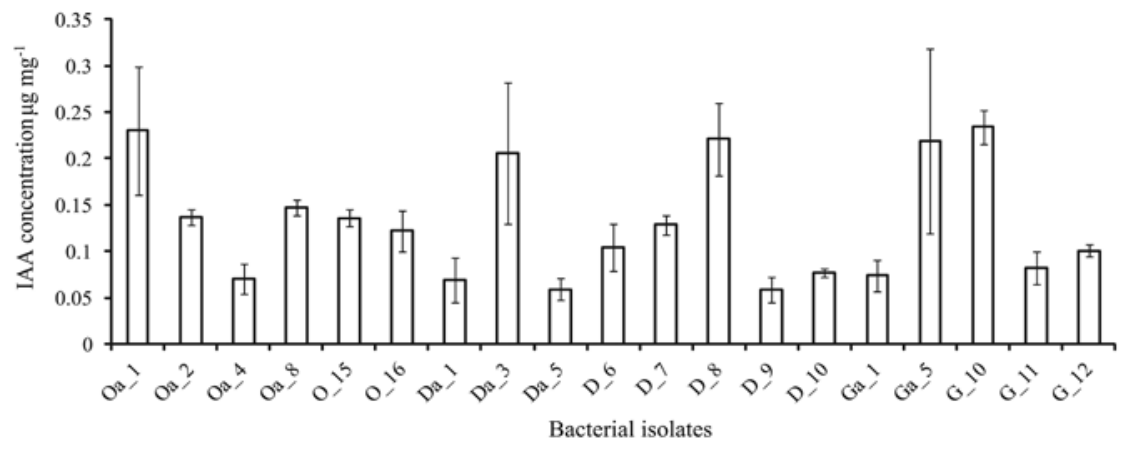

Figure 1. Production of indole-3-acetic acid (IAA) by endophytic bacteria isolates from apple (data is presented as mean and standard deviation)

endophytes were extensively studied in legume plants. Santi et al. (2013) demonstrated that non-legume plants contain a diversity of nitrogen fixing endophytes as well, and their composition depends not only on plant species but also on the environmental conditions. In our study, twenty five (approx. 66\%) of the isolates were found to be able to assimilate molecular nitrogen (Table 2).

Tricalcium phosphate solubilization activity is the plant growth promoting property that is characteristic of plant-associated bacteria of rhizosphere. Solubilization of tricalcium phosphate by endophytes may improve the solubilization of the fixed soil phosphorus resulting in higher yields and stress tolerance (Banerjee et al., 2010). Our analysis demonstrated that twelve of the isolates had the ability to solubilize tricalcium phosphate (Table 2). Presence of the tricalcium phosphate solubilization activity among the bacteria inhabiting the apple phylosphere might suggested that, despite spatial separation between the rhizosphere and the phylosphere of perennial trees, the same strains of bacterial endophytes could inhabit both of the plant parts and the rhizosphere would represent the major source of endophytic bacteria. Further study on the endophyte migration route in tree plants could establish the origin of different species of the apple endophyte population.

Our study showed that methylotrophy was a common trait of the endophytic bacteria in apple as seventeen (approx. 45\%) of the isolated bacterial strains demonstrated capability to use methanol as carbon source (Table 2).

Biochemical properties such as siderophore and hydrogen cyanide production were shown to be important as a plant growth promoting trait as well as for microbial antagonism. Lacava et al. (2008) reported that many plants are able to use the siderophores produced by bacterial endophytes as main iron source. In addition, siderophores can inhibit the growth of pathogenic microorganisms, therefore they acts as a pathogen biocontrol agent and indirectly stimulate the growth of plant (Glick, 2012). A majority of the apple endophytes isolated in our study demonstrated the capability to produce siderophores in response to iron deficiency. Eight isolates were tested positive for both, the siderophore and hydrogen cyanide production, including the identified strains O_14 (Pseudomonas fluorescens group), O_10 and Ga_5 (Pāntoea) (Table 2). As it was observed for other plant growth promoting traits, the presence of hydrogen cyanide and siderophore production traits varied among the isolates of $P$. fluorescens group.

To further examine the antimicrobial properties of the endophytes, an ability to suppress microbial growth by the culture filtrates of the endophytic isolates was assessed. Five common environment and pathogenic bacteria strains were used as reporter microorganisms. Culture filtrates of seventeen isolates were able to inhibit growth of Micrococcus luteus, four - Pseudomonas aeruginosa, two - Escherichia coli and Bacillus subtilis (Table 2). There was no suppression of growth of Salmonella typhimurium observed for the tested isolates. None of the culture filtrates was inhibiting growth of all four bacterial strains, but the most diverse activity was characteristic of strain Oa_6 that suppressed three out of five reporter microorganisms. Although one of the isolates (Oa_6) was a producer of siderophores, in general, the traits of hydrogen cyanide and siderophore production were only weekly related to the microbial growth suppression properties of the culture filtrates.

Previously, a chitinase production was demonstrated for the endophytes isolated from Poa ampla, Festuca arundinacea, Lolium perenne, Festuca rubra plants (Li et al., 2004). Chitinase enzymes break down glycosidic bonds in chitin and acts as an antifungal agent. We observed that 13 of the apple endophyte isolates were able to produce chitinase and had the potential to inhibit fungal growth (Table 2). In addition, application of the sterile culture filtrates of the endophytic isolates to apple scab pathogen Venturia inaequalis culture revealed that three of the isolates (D 8, D 10 and D 7) were able to inhibit the growth of $V$. inaequalis (Fig. 2 ). The isolates D_8 and D_10 identified as Pantoea species were shown

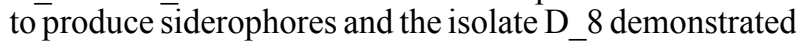
chitinase activity and production of hydrogen cyanide, as well. These biochemical traits might be related to the inhibition of growth of the fungal pathogen $V$. inaequalis by the endophytic strains of Pantoea sp. However, the 
results of biochemical tests did not reveal any hints about the potential mechanism of antifungal properties of the P. fluorescens strain (isolate D_7).

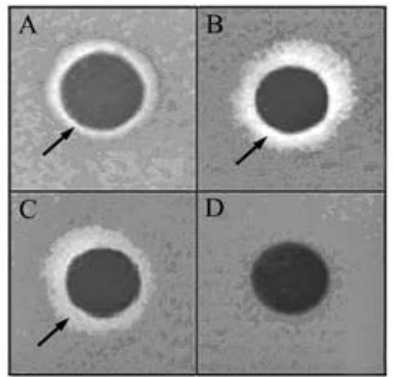

Notes. Clear zones of inhibition (indicated by arrow) indicate growth suppression of apple scab by culture filtrates of the bacterial isolates D 7 (A), D 8 (B) and D 10 (C). Effect of the isolate D_9 (D) shown as representative example of absence of the growth suppressing activity.

Figure 2. Venturia inaequalis growth suppressing activity of bacterial endophytes

The observation of antimicrobial and $V$. inaequalis suppressing activity among the bacterial isolates from apple endosphere suggested that the endophytic bacteria might play a role in apple disease resistance. Further study of pathogenicity and effect on plant growth and disease resistance would reveal potential of the bacteria as a biocontrol agent for apple scab disease. Members of the genus Pantoea were found among the plant associated bacteria of perennial woody plants, and were isolated from apple (Smits et al., 2010; Bulgari et al., 2012), eucalyptus (Brady et al., 2009) and citrus (Quecice et al., 2012) plants previously. The biocontrol potential of Pantoea sp. was studied by Smits et al. (2010), and Pantoea vagans (syn. Pantoea agglomerans) strain C9-1 was commercially registered as the biological control agent for fire blight (Erwinia amylvora).

\section{Conclusions}

1. Our study revealed the presence of diverse population of endophytic bacteria in apple phyllosphere. Thirteen isolates were assigned to Curtobacterium, Pantoea and Pseudomonas species. Genus Pseudomonas was found dominant among the identified isolates.

2. Plant growth promoting traits, such as nitrogen fixation and production of indole-3-acetic acid (IAA), were common (approx. $66 \%$ and $50 \%$ of the isolates, respectively) among the endophytic bacteria from apple phyllosphere. Concentration of the IAA in culture medium varied between 10 and $68 \mu \mathrm{g} \mathrm{ml}^{-1}$ of bacterial protein content, and Pantoea sp. isolates were the largest producers of IAA.

3. A large proportion of the isolates demonstrated biochemical traits important for microbial growth suppression, such as hydrogen cyanide, siderophore and chitinase production. Culture filtrates of seventeen endophytic isolates were able to inhibit growth of common non-pathogenic and pathogenic bacterial strains, three isolates identified as Pantoea sp. and Pseaudomonas sp. inhibited growth of apple scab pathogen.

\section{Acknowledgements}

The research was funded by The European Social Fund under the Global Grant measure (grant No. VP1-3.1-ŠMM-07-K-01-041).

\section{References}

Ahmad F., Ahmad I., Khan M. S. 2008. Screening of freeliving rhizospheric bacteria for their multiple plant growth nromoting activities. Microbiologv Research. 163: 173-181 http://dx.doi.org/10.1016/j.micres.2006.04.001

Baida N., Yazourh A., Singer E., Izard D. 2002. Pseudomonas grimontii sp. nov. International Journal of Systematic and Evolutionary Microbiology, 52: 1497-1503 http://dx.doi.org/10.1099/00207713-52-5-1497

Banerjee G., Scott-Craig J. S., Walton J. D. 2010. Improving enzymes for biomass conversion: a basic research perspective. Bioenergy Research, 3: 82-92 http://dx.doi.org/10.1007/s12155-009-9067-5

Behrendt U., Ulrich A., Schumann P., Naumann D., Suzuki K. 2002. Diversity of grass-associated Microbacteriaceae isolated from the phyllosphere and litter layer after mulching the sward; polyphasic characterization of Subtercola pratensis sp. nov., Curtobacterium herbarum sp. nov. and Plantibacter flavus gen. nov., sp. nov. International Journal of Systematic and Evolutionary Microbiology. 52: 1441-1454 http://dx.doi.org/10.1099/00207713-52-5-1441

Behrendt U., Ulrich A., Schumann P. 2003. Fluorescent pseudomonads associated with the phyllosphere of grasses; Pseudomonas trivialis sp. nov., Pseudomonas poae sp. nov. and Pseudomonas congelans sp. nov. International Journal of Systematic and Evolutionary Microbiology, 53: 1461-1469 http://dx.doi.org/10.1099/ijs.0.02567-0

Bianco C., Imperlini E., Defez R. 2009. Legumes like more IAA. Plant Signaling and Behavior, 4: 763-765 http://dx.doi.org/10.4161/psb.4.8.9166

Brady C. L., Venter S. N., Cleenwerck I., Engelbeen K., Vancanneyt M., Swings J., Coutinho T. A. 2009. Pantoea vagans sp. nov., Pantoea eucalypti sp. nov., Pantoea deleyi sp. nov. and Pantoea anthophila sp. nov. International Journal of Svstematic and Evolutionary Microbiology, 59: 2339-2345 http://dx.doi.org/10.1099/ijs.0.009241-0

Brown G. R., Hem V., Katz K. S., Ovetsky M., Wallin C., Ermolaeva O., Tolstoy I., Tatusova T., Pruitt K. D., Maglott D. R., Murphy T. D. 2015. Gene: a gene-centered information resource at NCBI. Nucleic Acids Research, 43: D36-D42 http://dx.doi.org/10.1093/nar/gku1055

Bulgari D., Bozkurt A. I., Casati P., Caglayan K., Quaglino F., Bianco P. A. 2012. Endophytic bacterial community living in roots of healthy and 'Candidatus Phytoplasma mali'infected apple (Malus domestica, Borkh.) trees. Antonie Van Leeuwenhoek, 102: 677-687 http://dx.doi.org/10.1007/s10482-012-9766-3

Cai G., Wang X. 2012. Isolation, identification and bioactivity of endophytic fungi from medicinal plant Malus sieboldii. Journal of Chinese Materia Medica, 37: 564-568

Camatti-Sartori V., Silva-Ribeiro R. T., ValdebenitoSanhueza R. M., Pagnocca F. C., Echeverrigaray S., Azevedo J. L. 2005. Endophytic yeasts and filamentous fungi associated with southern Brazilian apple (Malus domestica) orchards subjected to conventional, integrated or organic cultivation. Journal of Basic Microbiology, 45: 397-402 http://dx.doi.org/10.1002/jobm.200410547

Davies P. J. 2010. Plant hormones: their nature, occurrence, and functions. Plant hormones. p. 1-5 http://dx.doi.org/10.1007/978-1-4020-2686-7

Elbeltagy A., Nishioka K., Sato T., Suzuki H., Ye B., Hamada T., Isawa T., Mitsui H., Minamisawa K. 2001. Endophytic colonization and in planta nitrogen fixation by a Herbaspirillum sp. isolated from wild rice species. Applied and Environmental Microbiologv. 67: 5285-5293 http://dx.doi.org/10.1128/AEM.67.11.5285-5293.2001

Glick B. R. 2012. Plant growth-promoting bacteria: mechanisms and applications. Scientifica. 2012: 1-15 http://dx.doi.org/10.6064/2012/963401

Gordon S. A., Weber R. P. 1951. Colorimetric estimation of indoleacetic acid. Plant Physiology. 30: 86-88 http://dx.doi.org/10.1104/pp.26.1.192

Hata K., Atari R., Sone K. 2002. Isolation of endophytic fungi from leaves of Pasania edulis and their within-leaf distributions. Mycoscience. 43: 369-373 http://dx.doi.org/10.1007/S102670200054 
Lacava P. T., Silva-Stenico M. E., Araujo W. L., Simionato A. V., Carrilho E., Tsai S. M., Azevedo J. L. 2008. Detection of siderophores in endophytic bacteria Methylobacterium spp. associated with Xylella fastidiosa subsp. Pauca. Pesquisa Agronecuaria Brasileira, 43: 521-528 http://dx.doi.org/10.1590/S0100-204X2008000400011

Lata H., Li X. C., Silva B., Moraes R. M., Halda-Alija L. 2006. Identification of IAA-producing endophytic bacteria from micropropagated Echinacea plants using 16S rRNA sequencing. Plant Cell, Tissue and Organ Culture, 85: 353-359 http://dx.doi.org/10.1007/s11240-006-9087-1

Li H. M., Sullivan R., Moy M., Kobayshai D. Y., Belnngerl F. C. 2004. Expression of a novel chitinase by the fungal endophyte in Poa ampla. Mycologia, 96: 526-553 http://dx.doi.org/10.2307/3762172

Mehta S., Nautiyal C. S. 2001. An efficient method for qualitative screening of phosphate-solubilizing bacteria Current Microbiology, 43: 51-56 $\mathrm{http}: / /$ dx.doi.org/10.1007/s002840010259

Miliūtè I., Buzaite O. 2011. IAA production and other plant growth promoting traits of endophytis bacteria from apple tree. Biologiia, 57 (2): 98-102 http://dx.doi.org/10.6001/biologija.v57i2.1835

Quecice M. C., Araujo W. L., Rossetto P. B., Ferreira A., Tsui S., Lacava P. T., Mondin M., Azevedo J. L., PizziraniKleiner A. A. 2012. Sugarcane growth promotion by the endophytic bacterium Pantoea agglomerans 33.1. Applied and Environmental Microbiologv, 78: 7511-7518 http://dx.doi.org/10.1128/AEM.00836-12

Raddadi N., Cherif A., Boudabous A., Datfonchio D. 2008. Screening of plant growth promoting traits of Bacillus thuringiensis. Annals of Microbiology, 58: 47-52 http://dx.doi.org/10.1007/BF03179444
Rodriguez J., White J. F., Arnold A. E., Redman R. S. 2008. Fungal endophytes: diversity and functional roles. New Phytologist, 182: 314-330 http://dx.doi.org/10.1111/j.1469-8137.2009.02773.x

Rosenblueth M., Martinez-Komero E. 2006. Bacterial endophytes and their interactions with hosts. Molecular Plant Microbe Interactions. 19: 827-837 http://dx.doi.org/10.1094/MPMI-19-0827

Santi C., Bogusz D., Franche C. 2013. Biological nitrogen fixation in non-legume plants. Annals of Botany, 111: 743-767 http://dx.doi.org/10.1093/aob/mct048

Smits T. H., Rezzonico F., Kamber T., Goesmann A., Ishimaru C. A., Stockwell V. O., Frey J. E., Duffy B. 2010. Genome sequence of the biocontrol agent Pantoea vagans strain C9-1. Journal of Bacteriology, 192: 6486-6487 http://dx.doi.org/10.1128/JB.01122-10

Sozren K., Cekic C. D., Tutem E., Apak R. 2006. Spectrophotometric total protein assay with copper (ii)-neocuprine reagent in alkaline medium. Talanta, 68: 1601-1609 http://dx.doi.org/10.1016/j.talanta.2005.08.043

Vellore J. M. 2001. Iron acquisition in Rhodoccoccus erythropolis: the isolation of mutant(s) that do not produce a siderophore. Journal of Clinical Microbiology, 39: 147-155

Yan Y., Yang J., Dou Y., Chen M., Ping S., Peng J., Lu W., Zhang W., Yao Z., Li H., Liu W., He S., Geng L., Zhang X., Yang F., Yu H., Zhan Y., Li D., Lin Z., Wang Y., Elmerich C., Lin M., Jin Q. 2008. Nitrogen fixation island and rhizosphere competence traits in the genome of rootassociated Pseudomonas stutzeri A1501. Proceedings of the National Academv of Sciences of the IJSA. 105 (21): 7564-7569 http://dx.doi.org/10.1073/pnas.0801093105

Weisburg W. G., Barns S. M., Pelletier D. A., Lane D. J. 1991. 16S ribosomal DNA amplification for phylogenetic study. Journal of Bacteriology, 173: 697-703

ISSN 1392-3196 / e-ISSN 2335-8947

Zemdirbyste-Agriculture, vol. 103, No. 1 (2016), p. 77-82

DOI $10.13080 /$ z-a.2016.103.010

\title{
Naminės obels endofitinių bakterijų izoliatų augalų augimą skatinančios ir antagonistinès savybès
}

\author{
I. Miliūtè ${ }^{1}$, O. Buzaitè $\dot{1}^{1,2}$, D. Gelvonauskienè $\dot{1}^{1}$ A. Sasnauskas ${ }^{1}$, V. Stanys ${ }^{1,3}$, D. Baniulis \\ ${ }^{1}$ Lietuvos agrarinių ir miškų mokslų centro Sodininkystès ir daržininkystès institutas \\ ${ }^{2}$ Vytauto Didžiojo universitetas, Lietuva \\ ${ }^{3}$ Aleksandro Stulginskio universitetas, Lietuva
}

\section{Santrauka}

Endofitinès bakterijos yra plačiai paplitusios augalų audiniuose; nustatyta, kad jos reguliuoja augalų augimą ir pasižymi savybėmis, perspektyviomis augalų biologinei apsaugai. Nedaug tyrimų yra paskelbta apie kultūrinių sumedėjusių augalų, pavyzdžiui, naminès obels (Malus $\times$ domestica Borkh.), filosferos endofitines bakterijas. Todèl šio tyrimo tikslas - identifikuoti kultivuojamas endofitines bakterijas būdingas obels filosferai ir ištirti šiu endofitų augalų augimą skatinančias biochemines savybes bei mikroorganizmų augimą slopinančias savybes. Iš lauko sąlygomis auginamų veislių ‘Gala', ‘Golden Delicious' ir ‘Orlovim’ pumpurų buvo izoliuoti 38 kultivuojamų endofitinių bakteriju izoliatai, iš kurių 13 buvo identifikuoti kaip Curtobacterium, Pantoea ir Pseudomonas genčių bakterijos. Biocheminio aktyvumo savybių tyrimais įvertintos šių izoliatų augalų augimą skatinančios ir mikroorganizmų augimą slopinančios savybès - azoto fiksacija, idolo-3-acto rūgšties (IAR) gamyba, fosfatų tirpinimas, sideroforų ir ciano vandenilio gamyba. Keletui izoliatų buvo būdingas antagonistinis poveikis tirtoms nepatogeninėms ir patogeninėms bakterijoms: 17 izoliatų slopino Micrococcus luteus augimą, 4 - Pseudomonas aeruginosa, 2 - Escherichia coli ir Bacillus subtilis. Be to, nustatyta, kad du Pantoea sp. (D_8 ir D_10) izoliatai ir Pseudomonas fluorescens grupès izoliatas D 7 slopina obels patogeno obelinio rauplègrybio (Venturia inaequalis (Cke) Wint.) augimą, todèl galima daryti priēāidą, kad endofitai gali būti svarbūs didinant augalų atsparumą ligoms ir kuriant biologinės kontrolès priemones.

Reikšminiai žodžiai: antimikrobinis aktyvumas, biologinè kontrolè, filosfera, Malus $\times$ domestica.

Please use the following format when citing the article:

Miliūtė I., Buzaitė O., Gelvonauskienė D., Sasnauskas A., Stanys V., Baniulis D. 2016. Plant growth promoting and antagonistic properties of endophytic bacteria isolated from domestic apple. Zemdirbyste-Agriculture, 103 (1): 77-82 DOI 10.13080/z-a.2016.103.010 